\title{
Geodata for the urban environment
}

\author{
H. J. Reeves ${ }^{1 *} \&$ T. R. West ${ }^{2}$ \\ ${ }^{1}$ British Geological Survey, Kingsley Dunham Centre, Keyworth, Nottingham NG12 5GG, UK \\ 2 Purdue University, Department of Earth and Atmospheric Science, West Lafayette, IN 47907, USA \\ *Corresponding author (e-mail: hjre@bgs.ac.uk)
}

\begin{abstract}
Since the development of the first 2D urban geological map of Bath by William Smith in 1799, the production and representation of geological information has changed little until relatively recently. In the last 20 years, information technology and increased computing capacities have transformed the way in which geoscientists work. In particular, the development and use of geographic information systems (GISs) and modelling packages have meant that there is now a far greater opportunity to develop engineering geological products that show more effectively the third dimension in the urban environment. Because the information is captured and manipulated digitally, the outputs can be tailored to various end-user needs and more readily updated as new data become available. To illustrate these developments a brief overview of the 30 papers that were submitted to the Theme 'Geodata for the Urban Environment' of the 10th International Congress of the International Association for Engineering Geology and the Environment (IAEG) are presented and discussed.
\end{abstract}

Three-dimensional geological modelling is revolutionizing geological interpretation in the urban environment. It is a tool that, for the first time, is allowing geologists and engineering geologists to create and communicate, interactively, 3D geological and engineering geological models, which were previously developed as 2D images (maps and cross-sections) by combining ground investigation information and geological knowledge. For engineering applications in the urban environment, the modelling has provided a 3D framework for the spatial presentation and interpretation of geotechnical data (Culshaw 2005). From these spatial data, engineering geological classifications can be formulated and the engineering geological ground conditions visualized. Engineers and geologists can use these in urban environments to assist in the recognition and identification of problematic ground conditions (Reeves et al. 2005), as a tool to aid in the planning and location of ground investigations, and to ensure that the most economical and valuable information is obtained from ground surveys. By using examples from the 30 papers that were submitted to the Theme 'Geodata for the Urban Environment' of the 10th International Congress of the International Association for Engineering Geology and the Environment (IAEG) these concepts and ideas will be presented to demonstrate how engineering geological products can show the third dimension, allow the spatial attribution of geotechnical data and, hence, allow the effective communication of engineering geological information to audiences of specialist and non-specialist backgrounds.

\section{Summary of papers submitted to the Theme 'Geodata for the Urban Environment'}

In the 30 papers that were submitted to the Theme, five key Q1 topics that were covered: (1) the development of spatial databases for borehole and geotechnical information; (2) the development of GISs, for geoscientific purposes; (3) the development of dynamic 3D geoscientific computer models, which hold and manipulate large spatial datasets (such as borehole and geotechnical data); (4) the development of sophisticated knowledge-based and decision-making tools for a variety of specialist and non-specialist users; (5) examples and case studies of specific types of geodata used in the urban environment.

Of these topics, the first four will form the basis of the discussion in this paper. A brief summary of the highlights of each topic and some examples from the papers submitted to the Theme are discussed below. These summaries aim to indicate how engineering geological products can show the third dimension, allow the spatial attribution of geotechnical data, and hence allow the effective communication of engineering geological information to a wide range of users.

\section{Development of spatial databases}

Four papers were submitted on the topic of the 'Development of spatial databases'. These varied from papers that

From: Culshaw, M. G., Reeves, H. J., JefFerson, I. \& Spink, T. W. (eds) Engineering Geology for Tomorrow's Cities.

Geological Society, London, Engineering Geology Special Publications, 22, 209-213.

DOI: 10.1144/EGSP22.17 0267-9914/09/\$15.00 (C) The Geological Society of London 2009. 
presented the detailed design and specification of geotechnical databases (Ngan-Tillard et al. 2009; Oliveira et al. 2009) to more complex and integrated geoscientific database management systems as described by Kiehle et al. (2009) and Giles (2009).

Ngan-Tillard et al. (2009) discussed a large geotechnical database of cone penetration test (CPT) data that was developed by municipalities, scientific institutes and geotechnical engineering consultants in The Netherlands. Ngan-Tillard et al. (2009) demonstrated a specialist clustering tool's ability to analyse and effectively interpret the shallow subsurface from these data. In comparison, Oliveira et al. (2009) described a similar database (GEODATA) that has been complied for the Portuguese city of Oporto. This database formed an integral part to a larger engineering geological mapping programme of work in the city (see below in the section on 'Development of GISs for geoscientific purposes'). The GEODATA database consisted of three main modules that hold geophysical investigation information, mechanical investigation information and in situ test results.

The more complex and integrated geoscientific database management systems that have been produced as a result of recent developments in Geoinformatics have allowed systems as described by Kiehle et al. (2009) to be developed. This system is called the Spatial Data Infrastructure (SDI). It manages huge amounts of spatially related data and fosters the reuse of existing data inventories for future uses that are not yet known. The main building block of the hypothesis is that spatially related data are available in several places. The data storage and preparation is located with the data providers. The task of data preparation, manipulation and retrieval is carried out using Web services and, hence, is available to a multitude of users. In comparison, Giles (2009) described a similar system that the British Geological Survey (BGS) is developing (the BGS Geodata index).

All the papers discussed above highlight the important role that data and databases have in large geotechnical and engineering geological projects in the urban environment. With more information being available through wellmanaged systems, better results are produced. To supply the relevant information, all data have to be collected and stored in one place, which is an extensive task. Therefore, it is vital to have the correct infrastructure in place to acquire, manage and distribute the geoscientific information from these systems in a way that gives potential users confidence and the information that they want. Without the development of these well-designed and managed systems, valuable ground investigation data and information can be lost and, hence, not incorporated into current, as well as future, studies and investigations.

\section{Development of GISs for geoscientific purposes}

Eleven papers were submitted that covered the topic 'Development of Geographical Information Systems (GISs) for geoscientific purposes'. Collectively, the submitted papers highlighted various ways that a GIS can be used to aid geoscientific data visualization and investigations in urban environments. Papers submitted generally fell into two categories: (1) cartographic production and data holding of maps; (2) interrogation of spatial datasets using specialist tools and functionality. Many of the papers have demonstrated how a GIS can produce and manage information from geological, engineering geological and environmental mapping projects within the urban environment. For example, Mironov (2009) presented a project that described how a GIS was used to manage a geological mapping project that investigated ancient buried erosion valleys in Moscow. Similarly, Oliveira et al. (2009) produced a comprehensive engineering geological map of the city of Oporto. One output was a Geotechnical Zoning Map. The GIS and maps produced for this project are now used as an important tool for land-use planning and management in Oporto. A similar engineering geological GIS to manage an engineering geological mapping project proposed for the southeastern part of Brazil was discussed by Bastos \& Zuquette (2009).

In addition to the production and management of geological, engineering geological and environmental maps, a GIS also can be used to produce more complex maps with additional functionality. Four papers gave examples of this (Calijuror et al. 2009; Harrison \& Forster 2009; Mellon \& Q2 Frize 2009; Zhou \& Yao 2009). Mellon \& Frize (2009) presented a GIS-based system that centrally held spatial and tabular datasets. The key feature of this system was the seamless link from the GIS to a digital archive of scanned reports and borehole logs held in an electronic document management system. In comparison, Calijura et al. (2009), Q2 Harrison \& Forster (2009) and Zhou \& Yao (2009) demonstrated a slightly different application of a GIS, whereby a geo-referenced database was manipulated in a GIS environment. Calijura et al. (2009) discussed a risk map in an urban Q2 environment that was produced using this technique. The Chinese Geological Hazard Information System was described by Zhou \& Yao (2009), and they demonstrated how the stored geohazard information for China on landslides, land subsidence, debris flows, ground fissuring and other geohazards is managed. Harrison \& Forster (2009) described a similar project called GeoHazarD. This is described further below under the topic 'Knowledge-based and decision-making tools'.

One of the most powerful attributes of a GIS is the ability to interrogate spatial datasets using specialist tools and functionality. A number of papers gave examples of a GIS being used in this manner. Apolinário-Francisco et al. (2009), for example, described a GIS-based research project in the city of Brasilia, Brazil. This project made use of spatial analytical tools to investigate, estimate and model the loss of soil in this region. This study supported the socioeconomic and environmental planning in the short and medium term, as well as being able to model future scenarios of this geodynamic phenomenon. In comparison, MoredaMendes \& Lorandi (2009) and Choi \& Park (2009) demonstrated the use of geostatistical methods within a GIS environment to spatially analyse data. Moreda-Mendes 
\& Lorandi (2009) discussed how geostatistics (with indicator geostatistical resources) are used to create probabilistic maps, which show where the most favourable areas for constructing foundations at specific depths can be found in the São José do Rio Preto urban area (Brazil). Choi \& Park (2009), in comparison, demonstrated how, within a GIS environment, interrogation of data and 3D geostatistical methods can be used to predict variation of soil properties, such as hydraulic conductivity.

The key observation from all of the papers under this topic is how GISs, are now common tools of practice for geotechnical engineers and engineering geologists. They form a fundamental platform for data collection, visualization and communication of geotechnical and engineering geological information to a wide range of end-users (e.g. geologists, engineers, planners, the general public).

\section{Dynamic 3D computer models}

Dynamic 3D computer models are the most rapidly expanding research area within geoscience; this is mainly due to the increase in computing capacities and capabilities. Eight papers were submitted on this topic. Some papers looked at aspects of 3D geological modelling (Bourgine et al. 2009; Develeeschouwer \& Pouriel 2009; Neber et al. 2009; 3 Palmu et al. 2009) ranging from case studies to wider applications and the attribution of 3D geological models with geotechnical, engineering geological and other data. Breysse et al. (2009) and Bougine et al. (2009) presented a case study of geotechnical modelling undertaken at a town scale, which focused on the southern part of Bordeaux, France. The purpose of this work was to reinterpret the nearsurface geological model to develop information that was more useful for urban planning. In comparison, Neumann et al. (2009) depicted a project that was undertaken by the State Geological Survey of Saxony-Anhalt, Germany, where engineering geological maps of the city of Magdeburg with seven thematic map sheets were produced. From this, innovative interactive computer modelling techniques were applied using a 3D spatial modelling package with an interactive $3 \mathrm{D}$ modeller to create a $3 \mathrm{D}$ engineering geological model of the subsurface. A similar case study by Merritt et al. (2009) has been undertaken in Glasgow, UK, in collaboration with Glasgow City Council, which is discussed further below under the topic 'Knowledge-based and decision-making tools'.

The models discussed above are all generally based on urban centres but there were a few examples from the papers submitted that also dealt with more site-specific engineering geological modelling. Van Knapen \& Slob (2009) discussed an automated identification method for $3 \mathrm{D}$ engineering geological rock mass characterization of discontinuity sets, using the results from a terrestrial laser scanner survey. From this survey a dense point cloud was generated that represented the geometry of the scanned rock face. Through $3 \mathrm{D}$ surface reconstruction techniques the original rock face could be rebuilt and, hence, identification of the discontinuity sets and characterization of the rock mass could be undertaken. Using similar scanning technology, Rahman et al. (2009) were also able to quantify the surface roughness of discontinuities within a rock mass.

From the papers submitted under this topic, it is apparent that $3 \mathrm{D}$ computer modelling is starting to be used in a wide spectrum of applications, from regional 3D urban geological modelling to specialist site-scale projects. In addition, it is also being undertaken using a variety of tools and methods.

\section{Knowledge-based and decision-making tools}

The development of 'Knowledge-based and decisionmaking tools' cannot be undertaken without the development of information technology systems such as spatial databases, GISs for geoscientific purposes and dynamic 3D computer models. Knowledge-based and decision-making tools form the 'front end' or 'final end-product' of the information technology systems that are developed. As a result, they can take a multitude of forms and can portray data and information to a multitude of end-users, not just those with geological training and expertise. In the papers submitted under this topic, this approach was presented by Gocmez et al. (2009), Harrison \& Forster (2009), Li et al. (2009), Martin \& Toll (2009) and Merritt et al. (2009).

Merritt et al. (2009) presented a fully integrated geological model, where INSIGHT Geologische Softwaresysteme $\mathrm{GmbH}$ have developed, in collaboration with the BGS, a linked 3D geological and attributed property model for part of Glasgow, UK, which deals with several geoscientific issues (hydrogeological, geotechnical, engineering geological, geohazards and uncertainty). In contrast, Gocmez et al. (2009), Harrison \& Forster (2009), Li et al. (2009) and Martin \& Toll (2009) presented systems that are designed to deal with more specific problems.

For example, Harrison \& Forster (2009) described a rulebased system using ArcGIS that combines digital vector geological data. This system (GeoHazarD) integrated expert knowledge, national databases, multi-criterion analysis and a flexible rule-based approach to model the geohazard datasets of the UK (collapsible deposits, compressible ground, slope instability, running sand, shrink-swell (subsidence and heave) and dissolution). The major advantage of this system is that it produces a fully auditable trail leading to the final geohazard risk classification. This allows the assessment to be updated automatically following a revision of the primary datasets (e.g. by geological mapping). This system has allowed geohazard susceptibility maps of the UK to be produced, which contribute to a number of products that portray geohazard risk information to a number of end-users (e.g. insurers the general public, local authorities, engineering consultants).

In contrast, Li et al. (2009) described a very detailed highway tunnel decision-making system that has been applied to the Zhegu Mount highway tunnel, in the west of China. This system aimed to develop and improve the 
methods and techniques that are used when building a highway tunnel. The system synthesizes theory analysis and expert judgement and monitors measurements in a tunnel to allow the 'intelligent' classification of the wall rock, analysis and forecasting of wall rock stress, and analysis and forecasting of wall rock deformation. This process then allows the security of rock wall supporting structures to be assessed. Martin \& Toll (2009) have developed a similar system to that of Li et al. (2009), which is designed to address and manage the complex parameters and information required when undertaking a risk assessment exercise for a contaminated site. To assist with this process, at the preliminary stage of a ground investigation, a prototype knowledge-based system (ATTIC: Assessment Tool for The Investigation of Contaminated Land) and database have been developed to capture the wealth of scientific knowledge required and ensure that a structured approach to the investigation is undertaken.

The papers submitted to this topic have shown how the use of knowledge-based and decision-making tools is expanding. Such tools are now forming one of the principal techniques to communicate technical and complex geoscientific data and information to end-users who may or may not have a geoscientific background. These systems are helping to increase the effective use of geotechnical and engineering geological information in the urban environment.

\section{Concluding remarks}

A total of 30 papers were represented within the Theme 'Geodata for the Urban Environment' at the IAEG 10th International Congress. This paper provides a review of many of the papers submitted to this theme. The main conclusions from the papers that were submitted are that, as geoscientists, we can now: develop GIS and 3D computer models to hold, manipulate and query large databases (borehole, geotechnical) on a relatively standard desktop computer; produce dynamic upgradeable models that can be rapidly changed and developed to suit different purposes and requirements; attribute models with geotechnical to hydrogeological to geophysical property data; visualize and present geoscientific data and information to a wide range of end-users (geologists, engineering geologists, geotechnical engineers, civil engineers, planners and the general public).

From the discussion in the session, it was noted that when using GISs and developing 3D models it must not be forgotten that there are standards and procedures that are followed in engineering practice (e.g. Eurocodes, ASTM guidelines). Therefore, it is vital that the standards and procedures now start to take account of the new methods and techniques that geotechnical engineers and engineering geologists can use to manage and visualize geoscientific data. It is crucial that these standards and procedures are kept up to date and take account of new developments in information technology, so that practising geoscientists can ensure that they are following good practice.

\section{References}

Apolinário-Francisco, R., Valentin, E. F. D., Moreira de Souza, M. \& Walde, D. H. G. 2009. Erosion modeling in hydrographic pilot basins in Brasília (Federal District), Brazil. In: Culshaw, M. G., Reeves, H. J., Jefferson, I. \& SPINK, T. W. (eds) Engineering Geology for Tomorrow's Cities. Geological Society, London, Engineering Geology Special Publications, 22 [on CD-ROM insert, Paper 427].

Bastos, G. \& ZuQuetTe, L. 2009. Proposal for development of a database for engineering geological mapping. In: CULSHAW, M. G., Reeves, H. J., Jefferson, I. \& SpinK, T. W. (eds) Engineering Geology for Tomorrow's Cities. Geological Society, London, Engineering Geology Special Publications, 22 [on CD-ROM insert, Paper 195].

Bourgine, B., Dominique, S., Marache, A. \& Thierry, P. 2009. Tools and methods for constructing 3D geological models in the urban environment: the case of Bordeaux. In: Culshaw, M. G., Reeves, H. J., Jefferson, I. \& Spink, T. W. (eds) Engineering Geology for Tomorrow's Cities. Geological Society, London, Engineering Geology Special Publications, 22 [on CD-ROM insert, Paper 72].

Breysse, D., Piette, C., Marache, A. \& Fabre, R. 2009. Data analysis and geotechnical properties modelling of urban soils: case of Pessac, Gironde. In: Culshaw, M. G., ReEves, H. J., JefFerson, I. \& Spink, T. W. (eds) Engineering Geology for Tomorrow's Cities. Geological Society, London, Engineering Geology Special Publications, 22 [on CD-ROM insert, Paper 73].

Calijuri, M. L., Marchi, O. A., Guimarães, A. O. \& Lugão, W. G. 2009. Mapping of risk areas of the municipal district of Viçosa, Minas Gerais, Brazil. In: Culshaw, M. G., ReEves, H. J., JefFerson, I. \& SpInK, T. W. (eds) Engineering Geology for Tomorrow's Cities. Geological Society, London, Engineering Geology Special Publications, 22 [on CD-ROM Q2 insert, Paper 456].

CHOI, Y. \& PARK, H. 2009. Integrating GIS and 3D geostatistical methods for geotechnical characterization of soil properties. In: Culshaw, M. G., Reeves, H. J., Jefferson, I. \& SPINK, T. W. (eds) Engineering Geology for Tomorrow's Cities. Geological Society, London, Engineering Geology Special Publications, 22 [on CD-ROM insert, Paper 532].

Culshaw, M. G. 2005. From concept towards reality: developing the attributed 3D geological model of the shallow subsurface. Quarterly Journal of Engineering Geology and Hydrogeology, 38, 231-284.

Devleeschouwer, X. \& Pouriel, F. 2009. Brussels Urban Geology (BUG): a 2D and 3D model of the underground by means of GIS. In: Culshaw, M. G., ReEves, H. J., JefFerson, I. \& SPINK, T. W. (eds) Engineering Geology for Tomorrow's Cities. Geological Society, London, Engineering Geology Special Publications, 22 [on CD-ROM insert, Paper 420].

Giles, J. 2009. Geodata: use with confidence? In: Culshaw, M. G., ReEves, H. J., JefFerson, I. \& Spink, T. W. (eds) Engineering Geology for Tomorrow's Cities. Geological Society, London, Engineering Geology Special Publications, 22 [on CD-ROM insert, Paper 370]. 
Gocmez, B. D., Cekirge, N. \& VArdar, M. 2009. Effects of geological factors on urban planning: an example from the Termal settlement, Turkey. In: Culshaw, M. G., Reeves, H. J., JefFerson, I. \& SpInK, T. W. (eds) Engineering Geology for Tomorrow's Cities. Geological Society, London, Engineering Geology Special Publications, 22 [on CD-ROM insert, Paper 749].

HARRISON, M. \& FORSTER, A. 2009. The assessment of national scale geohazard potential through the application of GIS modelling. In: Culshaw, M. G., ReEves, H. J., JefFerson, I. \& SPINK, T. W. (eds) Engineering Geology for Tomorrow's Cities. Geological Society, London, Engineering Geology Special Publications, 22 [on CD-ROM insert, Paper 286].

Kiehle, C., Azzam, R. \& Fernandez-Steeger, T. M. 2009. Revealing distributed geoinformation for engineering geological applications. In: Culshaw, M. G., Reeves, H. J., JefFerson, I. \& SpInK, T. W. (eds) Engineering Geology for Tomorrow's Cities. Geological Society, London, Engineering Geology Special Publications, 22 [on CD-ROM insert, Paper 396].

Li, T., MENG, L., Li, Y. \& MoU, L. 2009. Construction information computer assisted decision making system for highway tunnels. In: Culshaw, M. G., Reeves, H. J., Jefferson, I. \& SPINK, T. W. (eds) Engineering Geology for Tomorrow's Cities. Geological Society, London, Engineering Geology Special Publications, 22 [on CD-ROM insert, Paper 592].

Martin, J. \& TOLL, D. 2009. The development of a data structure for the storage of preliminary site investigation data. In: Culshaw, M. G., Reeves, H. J., Jefferson, I. \& Spink, T. W. (eds) Engineering Geology for Tomorrow's Cities. Geological Society, London, Engineering Geology Special Publications, 22 [on CD-ROM insert, Paper 747].

Mellon, P. \& Frize, M. 2009. A digital geotechnical data system for the City of Glasgow. In: Culshaw, M. G., ReEves, H. J., JEFFERSON, I. \& SPINK, T. W. (eds) Engineering Geology for Tomorrow's Cities. Geological Society, London, Engineering Geology Special Publications, 22 [on CD-ROM insert, Paper 346].

Merritt, J., Entwisle, D. \& Monaghan, A. 2009. Integrated geoscience data, maps and 3D models for the City of Glasgow, UK. In: Culshaw, M. G., ReEves, H. J., Jefferson, I. \& SPINK, T. W. (eds) Engineering Geology for Tomorrow's Cities. Geological Society, London, Engineering Geology Special Publications, 22 [on CD-ROM insert, Paper 394].

Mironov, O. 2009. GIS technologies for geological environment studies in urban territories. In: Culshaw, M. G., Reeves, H. J., JefFERSON, I. \& SPINK, T. W. (eds) Engineering Geology for Tomorrow's Cities. Geological Society, London, Engineering Geology Special Publications, 22 [on CD-ROM insert, Paper 253].

Morenda-Mendes, R. \& LoRAndi, R. 2009. Indicator kriging geostatistical methodology applied to geotechnics project planning. In: Culshaw, M. G., ReEves, H. J., JefFerson, I. \& SPINK, T. W. (eds) Engineering Geology for Tomorrow's Cities. Geological Society, London, Engineering Geology Special Publications, 22 [on CD-ROM insert, Paper 527].
Neber, A., Aubel, J., Classon, F., Hoefer, S., Kunz, A. \& Sobisch, H. G. 2009. From the Devonian to the present: landscape and technogenic relief evolution in an urban environment. In: Culshaw, M. G., Reeves, H. J., JefFerson, I. \& SPInK, T. W. (eds) Engineering Geology for Tomorrow's Cities. Geological Society, London, Engineering Geology Special Publications, 22 [on CD-ROM insert, Paper 517].

Neumann, D., Schönberg, G. \& Strobel, G. 2009. 3D-modeling of ground conditions for the engineering geology map of the city of Magdeburg. In: Culshaw, M. G., REEVES, H. J., JEFFERSON, I. \& SPINK, T. W. (eds) Engineering Geology for Tomorrow's Cities. Geological Society, London, Engineering Geology Special Publications, 22 [on CD-ROM insert, Paper 444].

Ngan-Tillard, D., Kruse, G., Maccabiani, J. \& Mollé, J. 2009. Rapid exploration of (large) sets of cone penetration test data. In: Culshaw, M. G., Reeves, H. J., JefFerson, I. \& SPINK, T. W. (eds) Engineering Geology for Tomorrow's Cities. Geological Society, London, Engineering Geology Special Publications, 22 [on CD-ROM insert, Paper 198].

Oliveira, R., Gomes, C. \& Guimarães, S. 2009. Engineering geological map of Oporto: A municipal tool for planning and awareness of urban geoscience. In: CUlshaW, M. G., ReEves, H. J., JefFerson, I. \& SpinK, T. W. (eds) Engineering Geology for Tomorrow's Cities. Geological Society, London, Engineering Geology Special Publications, 22 [on CD-ROM insert, Paper 615].

Palmu, J.-P., OJala, A. E. K. \& Vanhala, H. 2009. 3D modelling of construction suitability in Espoo, Finland. In: CULSHAW, M. G., Reeves, H. J., JefFerson, I. \& Spink, T. W. (eds) Engineering Geology for Tomorrow's Cities. Geological Society, London, Engineering Geology Special Publications, 22 [on CD-ROM insert, Paper 583].

Rahman, Z., Slob, S. \& Hack, H. 2009. Deriving roughness characteristics of rock mass discontinuities from terrestrial laser scan data. In: Culshaw, M. G., ReEves, H. J., JefFerson, I. \& SPINK, T. W. (eds) Engineering Geology for Tomorrow's Cities. Geological Society, London, Engineering Geology Special Publications, 22 [on CD-ROM insert, Paper 437].

Reeves, H. J., Kessler, H., Freeborough, K. A., Lelliott, M., GunN, D. A. \& Nelder, L. M. 2005. Subgrade geology beneath railways in Manchester. In: Forde, M. C. (ed.) Proceedings of Railway Engineering 2005, London, UK. Engineering Technics Press, Edinburgh [on CD-ROM].

VAN KNAPEN, B. \& SLOB, S. 2009. Identification and characterisation of rock mass discontinuity sets using $3 \mathrm{D}$ laser scanning. In: Culshaw, M. G., Reeves, H. J., Jefferson, I. \& Spink, T. W. (eds) Engineering Geology for Tomorrow's Cities. Geological Society, London, Engineering Geology Special Publications, 22 [on CD-ROM insert, Paper 438].

Zhou, P. \& YAO, L. 2009. Landslide hazard early warning system in China and future trends. In: Culshaw, M. G., Reeves, H. J., JefFERSON, I. \& SPINK, T. W. (eds) Engineering Geology for Tomorrow's Cities. Geological Society, London, Engineering Geology Special Publications, 22 [on CD-ROM insert, Paper 805]. 